\title{
Harry Rainy, M.A., M.D., F.R.C.P.Ed. By Professor
}

J. Lorrain Smith, F.R.S.

$(\operatorname{Read}$ January 14, 1924.)

Dr Harry RaINy died on 4th January 1923 at his residence, 16 Great Stuart Street.

$\mathrm{He}$ was born in Glasgow in 1864, and it is of interest to note his connection with two Scottish families, the members of which were distinguished in Medicine, Divinity, and Literature. His grandfather was Professor of Medical Jurisprudence in the University of Glasgow, and his father was Surgeon to the Eye Infirmary of Glasgow. Principal Rainy, who was for many years the distinguished leader of the Free Church, was his uncle. His mother was a descendant of the Balfours of Pilrig, a family to which Robert Louis Stevenson was related.

With these traditions Dr Rainy early acquired a love of learning, and in due time also he revealed a broad and active interest in the social problems which arise alike in the work of the Church and in medical practice.

Dr Rainy's father died in Glasgow at an early age from typhus fever, and his family came to Edinburgh and lived in George Square in the house formerly occupied by Sir Walter Scott.

He attended Edinburgh Academy for his school education, and at the University he graduated in Arts before he took up the study of Medicine. In his Arts course his mind turned especially to the subjects of Mathematics and Physics, and he came under the inspiring influence of Chrystal and Tait.

In his Medical undergraduate course he consistently took the highest place among his fellows, and, at his graduation in 1891, he won the Ettles Scholarship, a much coveted honour, which is awarded to the most distinguished student of the year.

After graduation he spent some time in post-graduate study in London and Vienna, and during this period he gave special attention to Ophthalmology and Diseases of the Nervous System.

When he returned to Edinburgh he was appointed Resident Medical Officer in Chalmers Hospital. At that time Dr George Balfour was the visiting physician and Sir Patrick Heron Watson the visiting surgeon of the Hospital.

In 1894 he was appointed University Tutor in Clinical Medicine, and 
from this point onwards a large part of his time and energy were given to teaching.

The work of his post as Clinical Tutor led him to write, in 1897, a textbook on Clinical Methods, and in this he had the co-operation of Dr Robert Hutchison. This book was a valuable contribution to the working resources of medical schools and has passed through many editions.

In 1896 he was elected a Fellow of the Royal College of Physicians of Edinburgh, and he took an active part in the work of the College. For ten years he was Secretary of the College, and his period of service is remembered with gratitude by the Fellows. The higher interests of Medicine received from him unwearied attention, and the College warmly appreciated his disinterested devotion to the work of his office and his sound judgment on the questions which came up for consideration and decision. He was elected Vice-President of the College in 1921.

His work as a teacher of Medicine was the chief occupation of his life. His success as a Clinical Tutor was followed by teaching in the New Town Dispensary, in the Infirmary as a Clinical Physician on the staff, and in the Extra-mural School as a Lecturer on the Principles and Practice of Medicine. In all these offices he taught the art and science of Medicine with great success and much acceptation.

In 1912 he was appointed to a special Lectureship in the University on Physical Methods in the Treatment of Disease, a subject in which he found scope for his lifelong interest in the application of these methods to the investigation of disease.

He was not a voluminous writer. His desire was to secure data which would stand the last scrutiny of criticism, and this ambition curtailed the volume of his contributions to Medicine. In addition to the textbook on Clinical Methods, he wrote papers on a variety of subjects, among which may be mentioned "The Pathology of Friedreich's Ataxia," "Congenital Facial Diplegia due to Nuclear Lesions," "Skiagraphic Studies in Teratology," "Clinical Methods of Estimating Sugar in the Blood," "Dyspnœea as a Clinical Symptom."

He was the first in the Edinburgh School to use X-rays in Medicine, and, had he cared to give up the wider interests of general Medicine, he might have made the development of this subject his specialty. He gave much help in organising the Laboratory of Clinical Medicine in the Royal Infirmary.

His memory will be warmly cherished for his personality and lifelong service. His devotion to the scientific work of the Medical School and his active interest in social problems in the community will long be remembered with grateful appreciation. 